\title{
Epidemiological pattern of lung cancer in a tertiary care centre- A prospective observational study
}

\author{
Sreekala $\mathbf{C}^{1}, \mathbf{K}$. Anitha Kumari ${ }^{2}$, Jayaprakash $\mathbf{B}^{3}$ \\ ${ }^{1}$ Dr. Sreekala C, ${ }^{2}$ Dr. K. Anitha Kumari, ${ }^{3}$ Dr. Jayaprakash B, all authors are affiliated with Department of \\ Pulmonary Medicine, Medical College, Thiruvananthapuram, Kerala, India.
}

Address for Correspondence: Dr. Sreekala C, Navaneetham, APRA 307, Ajantha Pulli Lane, Pettah. PO, Chackai, Thiruvananthapuram. E-mail:drkalamurali8@gmail.com

\begin{abstract}
Background: Lung cancer is a leading cause of morbidity and mortality worldwide. An increasing incidence of lung cancer has been observed in India.Aim of the study: To evaluate epidemiological profile oflung cancer in a tertiary care centre, South Kerala. Methodology: Prospective observational study, conducted at Medical College, Thiruvananthapuram, South Kerala, in 160 consecutive patients with histopathological diagnosis of lungcancer. Data on demography, symptoms, smoking status, physical findings, diagnostic modalities, histological diagnosis, and TNM stagewere recorded using a structured questionnaire. For inferential statistics, comparison between groups of qualitative variables were analysed by chi-square test and quantitative variables were compared by student $t$ test. $P$ value of less than 0.05 was considered as level of significance.Results: Out of 160 consecutive lung cancer patients, $86.9 \%$ of patients were males. Male to Female ratio is 6.6: 1.50- $59 \mathrm{yrs}$ was the commonest age group affected. $11.3 \%$ were nonsmokers. $67.5 \%$ of smokers were having smoking index more than 500.COPD was the commonest co morbidity (58\%) in the study.Adenocarcinoma (41.9\%) was the commonest histological type in our study and this was the commonest histologicaltype seen in females and nonsmokers. In smokers, squamous cell carcinoma (91.3\%) was more common. 66.9\% of patients were at TNM stage 3 or 4 at the time of diagnosis only $5 \%$ of patients were in surgically resectable stage. Conclusion: It was found out that Adenocarcinoma was the most frequent histopathological type and majority of patients were at advanced stage at the time of diagnosis.
\end{abstract}

Keywords: Lung Cancer, Comorbidity, TNM Stage, Adenocarcinoma

\section{Introduction}

Lung cancer has varied epidemiology depending on the geographic region. Globally, there have been important changes in incidence trends amongst men and women, histology, and also incidence in nonsmokers [1]. Several epidemiological observations performed across varied demographic cohorts in India confirm the significant burden of lung cancer in India [2]. Smoking tobacco, both cigarettes and beedis, is the principal risk factor for causation of lung cancer in Indian men; however, among Indian women, the association with smoking is not strong, suggesting that there could be other risk factors besides smoking [2]. There is a dearth in our current understanding of the changing

Manuscript received: $4^{\text {th }}$ September 2017

Reviewed: $14^{\text {th }}$ September 2017

Author Corrected: $20^{\text {th }}$ September 2017

Accepted for Publication: 26 ${ }^{\text {th }}$ September 2017 epidemiological trends of lung cancer among Indian patients. While the global trend of a rise in adenocarcinoma appears to be paralleled in India, we do not completely understand the alarming rise in the incidence of lung cancer among the nonsmokers. [2]. The survey conducted in Uttar Pradesh by Misra and others showed that the incidencewas 4.2 per 10,000 hospital admissions and $2 . \%$ of all malignancies [3]. As per data from the ICMRCancer Registry, males predominate with a male to female ratio of $4.5: 1$ and this ratio varies with age and smoking status.The ratio increases progressively upto 51 - 60 years and then remains the same. Upto 40 years of age,small-cell type predominates and has less association with smoking. After the age of 40 years, squamous cell type is thecommonest in smokers and 
adenocarcinoma in nonsmokers [3].The association of smoking and lung cancer is well known. The smoker to non-smoker ratiois high upto $20: 1$ in various studies. The risk increases with the amount and duration of smoking. In Indian patients with lung cancer, history of active tobacco smoking was found in $87 \%$ of males.

History of passive tobacco exposure is found in $3 \%$. So $90 \%$ of all cases result from tobacco exposure [3]. Indian epidemiological data on lung cancer is scarce.

We conducted the study to evaluate epidemiological profile oflung cancer in a tertiary care centre, South Kerala.

\section{Methodology}

Aim of study.Toevaluate epidemiological profile oflung cancer in a tertiary care centre, South Kerala.

Study Design. A prospective observational study over a period of twoyears.

Study Setting: Department of Pulmonary Medicine and Department of Oncology, Medical College, Thiruvananthapuram, Kerala, India

Study population: 160 consecutive patients with histopathological diagnosis aslung cancer,

\section{Results}

160 consecutive lung cancer patients were included. diagnosed at Pulmonary Medicine Department or cases of lung cancers referred fromelsewhere to Department of Oncology, Medical College, Thiruvananthapuram, Kerala over a period of two years.

Inclusion criteria: All cases of lung cancer withhistological proof, willing to participate in the studywere included.

Exclusion criteria: Patients withmalignancies other than lung cancer were excluded.

Data collection:Information on demography, symptomatology, physical finding, diagnostic modalities, histopathological type of lung cancer, extent of disease according TNM classification, smoking status, comorbidities and treatment details, were collected by patient interview andmedical records using structured questionnaire, after getting written consent from patients.

Institutional ethical committee clearance was obtained.

Statistical analysis: Data analysis was done using statistical package for social science (SPSS)-10 Version. For inferential statistics between groups, comparison of qualitative variables wereanalysed by chi-square test and quantitative variables were compared by student's t- test. $\mathrm{P}$ value of less than 0.05 was considered as level of significance.

Table-1: Age distribution.

\begin{tabular}{|c|c|c|}
\hline Age (in years) & Frequency & Percentage \\
\hline $30-39$ & 4 & 2.5 \\
\hline $40-49$ & 21 & 13.1 \\
\hline $50-59$ & 62 & 38.8 \\
\hline $60-69$ & 30 & 18.8 \\
\hline$>=70$ & 43 & 26.9 \\
\hline
\end{tabular}

50- 59 yrs was the commonest age group affected. Only $2.5 \%$ patents were below 40 years of age.

Table-2: Gender distribution.

\begin{tabular}{|c|c|c|}
\hline Sex & Frequency & Percentage \\
\hline Male & 139 & 86.9 \\
\hline Female & 21 & 13.1 \\
\hline Total & $\mathbf{1 6 0}$ & $\mathbf{1 0 0}$ \\
\hline
\end{tabular}

$86.9 \%$ were males and $13.1 \%$ were females.Male: female ratiowas $6.6: 1$. 
Table-3: Smoking status.

\begin{tabular}{|c|c|c|}
\hline History of smoking & Frequency & Percentage \\
\hline Non smoker & 18 & 11.3 \\
\hline $50-200$ & 13 & 13.1 \\
\hline $200-500$ & 21 & 40.6 \\
\hline $500-1000$ & 65 & 26.9 \\
\hline$>1000$ & 43 & 13.1 \\
\hline
\end{tabular}

$88.7 \%$ were smokers and $11.3 \%$ were non smokers. Out of smokers, $67.5 \%$ were having smoking index more than 500 .

Table-4: Frequencyof comorbidities.

\begin{tabular}{|c|c|c|}
\hline Comorbidity & Frequency & Percentage \\
\hline COPD & 93 & 58 \\
\hline Anaemia & 80 & 20 \\
\hline PulmonaryTB(Treated/Untreated) & 32 & 3 \\
\hline Asthma & 5 & 2 \\
\hline Family History of Ca(GIT) & 3 & 6 \\
\hline CAD & 10 & 50 \\
\hline
\end{tabular}

COPD is the commonest Co morbidity encountered (58\%) followed by anaemia $(50 \%)$

Table-5: Histological pattern.

\begin{tabular}{|c|c|c|}
\hline Histology & Frequency & Percentage \\
\hline Squamous cell carcinoma & 46 & 28.8 \\
\hline Adino carcinoma & 67 & 16.9 \\
\hline Small cell carcinoma & 26 & 2.5 \\
\hline Large cell carcinoma & 4 & 10.6 \\
\hline Non-specific & 17 & 16.3 \\
\hline
\end{tabular}

Adenocarcinoma was the commonest histological pattern in the study $(41.9 \%)$ followed bysquamous cellcarcinoma $(28.8 \%)$.

Table- 6: Staging of lung cancer.

\begin{tabular}{|c|c|c|}
\hline TNM & Frequency & Percentage \\
\hline Stage I & 3 & 1.9 \\
\hline Stage II & 22 & 13.8 \\
\hline Stage IIIa & 15 & 9.4 \\
\hline Stage IIIb & 21 & 30.6 \\
\hline Stage IV & 49 & 3.1 \\
\hline Limited stage & 5 & 13.8 \\
\hline Extensive stage & 22 & 14.4 \\
\hline Stage unknown & 23 & \\
\hline
\end{tabular}

$57.5 \%$ of study population were at advanced stage at the time of diagnosis. 
Table.7. Correlation ofgender and histology

\begin{tabular}{|c|c|c|c|c|c|}
\hline Sex & $\begin{array}{c}\text { Sqamous cell } \\
\text { carcinoma }\end{array}$ & Adenocarcinoma & $\begin{array}{c}\text { Small cell } \\
\text { carcinoma }\end{array}$ & $\begin{array}{c}\text { Large cell } \\
\text { carcinoma }\end{array}$ & Non specific \\
\hline Male & $\begin{array}{c}42 \\
(91.3 \%)\end{array}$ & $\begin{array}{c}50 \\
(74.6 \%)\end{array}$ & $\begin{array}{c}26 \\
(100 \%)\end{array}$ & $\begin{array}{c}17 \\
(100 \%)\end{array}$ \\
\hline Female & 4 & 17 & & & \\
\hline
\end{tabular}

Adenocarcinoma was the commonest histological pattern seen in females.

Table- 8: Smoking and histological pattern.

\begin{tabular}{|c|c|c|c|c|c|}
\hline Smoking & $\begin{array}{l}\text { Squamous Cell } \\
\text { Carcinoma }\end{array}$ & $\begin{array}{c}\text { Adino } \\
\text { Carcinoma }\end{array}$ & $\begin{array}{l}\text { Small Cell } \\
\text { Carcinoma }\end{array}$ & $\begin{array}{l}\text { Large Cell } \\
\text { Carcinoma }\end{array}$ & Non-specific \\
\hline \multirow[t]{2}{*}{ Non Smoker } & 4 & 14 & - & - & - \\
\hline & $8.70 \%$ & $20.90 \%$ & & & \\
\hline \multirow[t]{2}{*}{$50-200$} & 2 & 9 & 2 & - & - \\
\hline & $4.30 \%$ & $13.40 \%$ & $7.70 \%$ & & \\
\hline \multirow[t]{2}{*}{$200-500$} & 5 & 16 & - & - & - \\
\hline & $10.90 \%$ & $23.90 \%$ & & & \\
\hline \multirow{2}{*}{$500-1000$} & 11 & 17 & 20 & 4 & 13 \\
\hline & $23.90 \%$ & $25.40 \%$ & $76.90 \%$ & $100 \%$ & $76.50 \%$ \\
\hline \multirow[t]{2}{*}{$>1000$} & 24 & 11 & 4 & - & 4 \\
\hline & $52.20 \%$ & $16.40 \%$ & $15.40 \%$ & & $23.50 \%$ \\
\hline
\end{tabular}

Adenocarcinomawas the commonest histological type seen in non smokers.Among squamous cell carcinomapatients $91.3 \%$ are smokers.

Table.- 9. Treatment modalities.

\begin{tabular}{|c|c|c|}
\hline Treatment & Frequency & Percentage \\
\hline Surgery + Chemotherapy & 8 & 5 \\
\hline Chemotherapy + Radiotherapy & 152 & 95 \\
\hline
\end{tabular}

Only $5 \%$ of patientswere in surgicallyresectable stage. All patients received chemotherapy.

\section{Discussion}

Lung cancer has varied epidemiology depending on the geographic region. Globally, there have been important changes in incidence trends amongst men and women, histology, and incidence in nonsmokers. Indian epidemiological data on lung cancer is scarce [1]. In the developed countries, incidence and mortality from lung cancer in females is rising, whereas it is declining in males [4,5]. Cigarette smoking is the main risk factor for lung cancerand tripling of the number of cigarettes smoked per day triple the risk, while tripling of the duration of smoking was estimated to increase the lung cancer risk hundred fold (Doll, 1956). A metaanalysis of 41 studies of tobacco exposure shows that there is a relative risk of developing lungcancer of 1.48 in males and 1.2 in females [3]. There is global trend of rise in adenocarcinoma oflung. But various studies showed conflicting results regarding histopathological type of lung cancer in India [1,5]. This is a prospective study in 160 consecutive lung cancer patientsover a period of two years to find out epidemiological pattern of 
lungcancer in a tertiary carecenter in South India. In the study, $13.1 \%$ were females and $86.9 \%$ were males. Similar gender distribution was reported in the study by Yogeesha K.Set al [4]. Our study showed amale to femaleratio of $6.6: 1$. But in thestudy by Noronha $\mathrm{V}$ et almale-to-female ratio was 3.5:1 [1]. JagdishRawat, et al reported a comparatively higher prevalence in male i.e., 8.2:1 [5].

In our study, the commonest age group affected was 50-59 years.Similar findingwas reported by Yogeesha K. Set al [4]. Only $2.5 \%$ patients were below 40 years of age in our study, where as it was $6.5 \%$ in a previous study [4]

In this study, $11.3 \%$ were non smokers, but in a study byYogeesha K.Set al24.6\% were non smokers [4].

Out of smokers, $67.5 \%$ were having smoking index more than 500 in our study.Literature review also shows that the risk of lung cancer increases with the amount and duration of smoking[3].

COPD wasthe commonest comorbidity encountered $(58 \%)$ in our study. IslamK $\mathrm{M}$ et alreportedthat $52.5 \%$ of lung cancer patients were having COPD [6].

Adenocarcinoma was the commonest histological pattern in the study $(41.9 \%)$ followed by squamous cell carcinoma $(28.8 \%)$ in our study,simillar tothe results of previous studies. [1,7]. Among squamous cell carcinomapatients $91.3 \%$ are smokers. Previous studies also demonstrated the high incidence of squamous cell carcinoma in smokers $[1,5]$. In our study, $57.5 \%$ of study population were at advanced stage at the time of diagnosis, a finding similar to that reported by Noronha Vet al [1].Adenocarcinoma was the commonest histological pattern seen in female and in non smokersin the study as reported by earlier study [12].

In our study only $5 \%$ were at aresectable stage. Similar finding was reported by Noronha.Vet al where surgery was offered for $6 \%$ cases [1].

\section{Conclusion}

Majority of patients were males and smokers. Adenocarcinoma was the commonest histological pattern in our study, and were at an advanced stage at presentation. So early evaluation of symptomatic smokers may help to diagnose malignancy at an early stage.

\section{Funding: Nil, Conflict of interest: None Permission of IRB: Yes}

\section{References}

1. Noronha V, Dikshit R, Raut N, Joshi A, Pramesh C S, George K, Agarwal J P, Munshi A, Prabhash $\mathrm{K}$. Epidemiology of lung cancer in India: Focus on the differences between non-smokers and smokers: A single-centre experience. Indian J Cancer 2012; 49:74-81DOI: 10.4103/0019-509X.98925

2. Vanita Noronha, Rakesh Pinninti, Vijay M. Patil, Amit Joshi. Lung cancer in the Indian subcontinent.South Asian J Cancer. 2016 Jul-Sep; 5 (3): 95-103. doi: 10.4103/2278-330X.187571

3. D Behera. Epidemiology of lung cancer - Global and Indian perspective. JIACM 2012; 13 (2): 131-7.

4. Yogeesha K.S., Vijayamahantesh N.N., Raghavendra Bakki Sannegowda. Clinical presentation of lung cancer in adults: a retrospective study of 61 patients from a teritiary care centre in south India. International Journal of Basic and Applied Medical Sciences2014;4 (1:195-19.)

5. JagdishRawat, Girish Sindhwani, Dushyant Gaur, RuchiDua. Clinico-pathological profile of lung cancer in Uttarakhand. Lung India. 2009 JulSep; 26 (3): 74-76. doi: 10.4103/0970-2113. 53229

6. Islam KM, Jiang $\mathrm{X}$, Anggondowati $\mathrm{T}$, Lin $\mathrm{G}$, Ganti AK. Comorbidity and Survival in Lung Cancer Patients.Cancer Epidemiol Biomarkers Prev. 2015 Jul; 24(7):1079-85. doi: 10.1158/10559965. EPI-15-0036. Epub 2015 Jun 11.

7. Samir Dourmane, Merzak Gharnaout. Epidemiological and clinical profile of lung cancer in Algiers. European Respiratory Journal 2015 46: PA4309; DOI: 10.1183/13993003.

8. Prabhat Singh Malik and Vinod Raina. Lung cancer: Prevalent trends \& emerging concept. Indian J Med Res 2015 Jan; 141(1): 5-7. 


\section{Original Research Article}

9. Leduc C, Antoni D, Charloux A, Falcoz PE, Quoix E. Comorbidities in the management of patients with lung cancer. EurRespir J. 2017 Mar 29;49(3). pii: 1601721. doi: 10.1183/13993003. 01721-2016. Print 2017 Mar

10. Dubey AK, Gupta U, Jain S. Epidemiology of lung cancer and approaches for its prediction: a systematic review and analysis. Chinese Journal of Cancer 201635:71/doi.org/10.1186/s40880-0160135-x.
11. P. M. Parikh, A. A. RanadeBabuGovind, N. Ghadyalpatil, R. Singh. Lung cancer in India: Current status and promising strategies. South Asian J Cancer. 2016 Jul-Sep; 5(3): 93-95. doi: 10. 4103/2278-330X.187563.

12. Mohan A, Latifi AN, GuleriaR.Increasing incidence of adenocarcinoma lung in India: Following the global trend?Indian J Cancer. 2016 Jan-Mar; 53(1): 92-5. doi: 10.4103/0019-509X. 180819.

\section{How to cite this article?}

Sreekala C, K. Anitha Kumari, Jayaprakash B. Epidemiological pattern of lung cancer in a tertiary care centreA prospective observational study. Int J Med Res Rev 2017;5(09):839-844.doi:10.17511/ijmrr. 2017.i09.02. 